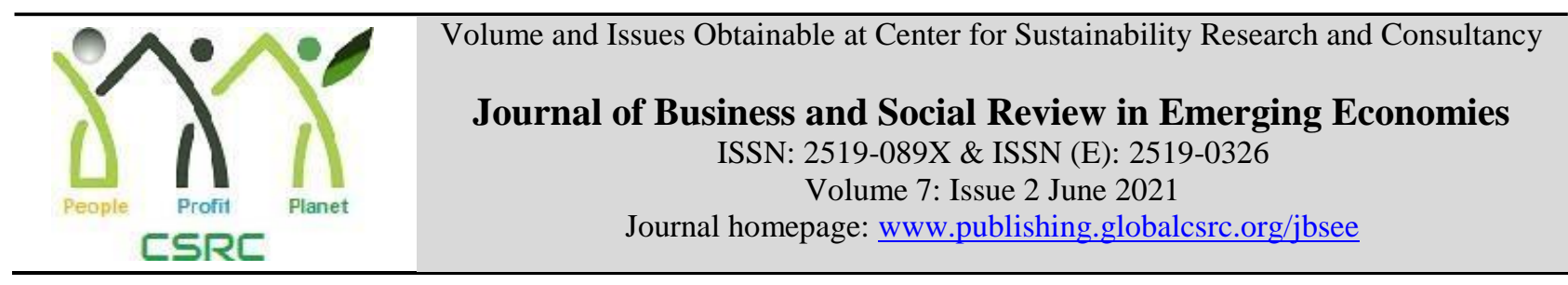

\title{
Student's Perception and Expectation Regarding Library Services Quality: A Case Study of a Public Multi Campus University of Punjab, Pakistan
}

\author{
*Shakeela Shah, Faculty of Education, University of Sindh, Jamshoro, Pakistan \\ Ghazal Khalid Siddiqui, University of Education, Lahore, Pakistan \\ Shaheen Pasha, Department of Special Education, University of Education, Lahore, Pakistan
}

*Corresponding author's email: shakeela@usindh.edu.pk

\begin{tabular}{l}
\hline ARTICLE DETAILS \\
\hline History \\
Revised format: May 2021 \\
Available Online: Jun 2021
\end{tabular}

Keywords

Service

SERVQUAL University

library

JEL Classification

IOO, 129

\section{ABSTRACT}

Purpose: The disparity between students' perceptions and expectations is measured in this study to determine the perceived service quality (SQ) of sample university's academic library units. Design/Methodology/Approach: Under the typology of quantitative approach survey method was used. The SERVQUAL instrument consisting of 22 items was adopted for assessing student's expectations and perceptions. The students enrolled in regular programmes of the academic year 2013-2014 were taken as population. Using stratified random sampling through proportional allocation, a sample of 372 respondents was designed. Data were analyzed quantitatively using descriptive statistics and qualitatively using NVIVO software for content of open-ended questions. Findings: The results revealed that student's expectations were higher than their perception. Implications/Originality/Value: Based on the findings, it was concluded that the concerned authorities may take initiatives to improve the library services provided by the library staff. In this way the students' expectations can be met.

(C) 2021 The authors, under a Creative Commons AttributionNonCommercial 4.0

Recommended citation: Shah, S., Siddiqui, G. K. \& Pasha, S. (2021). Student's Perception and Expectation Regarding Library Services Quality: A Case Study of a Public Multi Campus University of Punjab, Pakistan. Journal of Business and Social Review in Emerging Economies, 7 (2), 319-327.

\section{Introduction}

Over a few decades, the function of libraries has simply been revolutionized from the warehouse of books and other physical objects to information centers of access to databases in the advanced countries. Now, the main purpose of libraries and information centers is to provide a service to its 
users.

According to Ameen (2005) "increasing the size of the collection has been aim of libraries and considered a sign of greatness" (p.113). Until 19th century the aim of the libraries was to build and maintain big collection of books, manuscripts, pamphlets and magazines, etc. but their use was not considered important.

During the late 19th century librarians began to understand that the collection should be used for the personal help of users. Green (1876) was the first to present this notion. The Classical Five Laws of Ranganathan (1931) provided the user-centred philosophy that 'books are for use, every reader his or her book, every book its reader.

The role of a librarian is the mediator between user and library material. So, the. Librarian should serve the good of humanity by using library material (Cooke, 2004). Thus, the libraries have changed from the collection-centred to user-centred. Now the central purpose of libraries is to provide services to its users rather than simply the warehouse.

Rubin (2017) emphasized that the main change on the part of libraries began from 1980s after the invention of digital media like CD-ROM, OPACs, issue return and acquisition systems (p.64). The uprising of information was activated with the growth of computers and internet.

Meanwhile the cultural and financial changes around the libraries have a direct influence on the function of libraries. During the past forty years the function of the libraries has changed due to change in cultural environment. The programme of user care and satisfaction, reduction in public expenses was combined with financial decline in the 1980s (Crawford, 2006).

Due to fast advancement in technology, user's needs of information and expectations concerning the quality of library services has been multiplied. Now librarians and other library staff must have a proper classification and collection of books and provide required services to the users. Cultural and financial changes put multiple pressures on libraries to evaluate analytically SQ and show their value in relation to funds spent on them.

Service Quality is a 1990's phenomenon originated in the business and industry. The concept of SQ has been used in the service-oriented organizations including health, higher education institutions and libraries. The word "quality" has no single definition due to its numerous dimensions.

According to Evans and Lindsay (2004), the most common definition of SQ accepted by service marketing researchers is "Meeting or exceeding customer standards. The two important dimensions are objective quality and perceived quality. The perceived quality is user's judgement about the total quality of a service. The opinion of user is ranked significant for the evaluation of SQ.

According to Parasuraman et al. (1985), SQ perceptions came from contrast of user's expectations against perceptions. Mathematically this relationship can be best explained as;

$\mathrm{Q}=\mathrm{P}-\mathrm{E}$

Where $\mathrm{Q}=$ service quality, $\mathrm{P}=$ users' perception about service quality, and $\mathrm{E}=$ users' expectations about service quality.

For the analysis of perceived service quality performance, Durden (2000) divided the findings of this discrepancy into four groups i.e. 0 to $-1 ;-1$ to $-2 ;-2$ to -3 ; and -3 to -4 .

As per up-to-date information library management systems and the struggle from stake holders 
i.e. publishers, digital and Internet media, libraries are facing crises of existence and growth. A big variety of the studies in this field has revealed that the libraries face following contests under present day scenario:

Ever increasing user's expectations

Increasing usage of information technologies

Aadvancement of information technology

Explosion of knowledge

Struggle among suppliers and industries

The libraries have to evaluate their SQ, if they want to encounter the above-mentioned contests. In this way, the libraries will be able to understand whether they are meeting user's demands and expectations or not. The librarians are exercising marketing strategies to understand user's demands and desires, plan quality services, fulfil expectations and distribute the user- oriented services,

Assessing SQ is the first step in keeping customers in today's competitive environment, according to Cullen (2001). Evaluation of SQ contributes towards discovering SWOT regarding delivering quality library services. If the libraries want to provide quality library services, the evaluation of user's perceptions and expectations has a major part. Librarians have to take measures to improve their services and meet the expectations of the users.

Seay et al. (1996) stressed that users are only the stakeholders to evaluate the SQ. Users are better evaluators of SQ rather than the librarians, library patrons etc. Library holds duty which may confirm that it not only provides better services but also it fulfils the need of users. So a good library should be updated keeping in view the SQ and user satisfaction. Under the present circumstances the libraries especially the university libraries should evaluate their services to recheck their strengths and weaknesses.

Libraries are regarded as the 'Heart of Universities. The foremost objectives of a university are to provide education and produce research scholars. Therefore, the university libraries are bound to provide relevant information needed to their users involved in research activities.

It has become the prime responsibility of librarians to understand student's ever-changing needs and to offer correct and ready delivery of information to facilitate the process of education and research.

Pritchard (1996) stated that developing countries are moving ahead from the evaluation of SQ of libraries towards delivering quality services and ultimately incorporating principles of TQM into library management. So, the understanding regarding evaluation of library SQ in developing countries is rising gradually. In Pakistan an attempt was made by the researchers in the field of TQM to assess the quality of university library services by using SERVQUAL (Awan et al., 2007).

According to Naz (2006); Saeed \& Ramzan (2003); Samina (1991); and Samreen (2006), the following surveys on user satisfaction and studies on evaluation of total library SQ as well as specific library SQ have been organized in Pakistani Universities:

Reference Services

Reader's services

Availability of library material

Usability of OPAC 
The present study was conducted to evaluate SQ of the sample university Libraries. According to Higher Education Commission (2015) statistics, there are 153 universities in Pakistan. Majority of these Universities have modern library material. University of Education was established in the year 2002. It currently offers 25 degree programs ranging from B.Ed. to Ph.D. in its three Divisions and ten Campuses, and plans to offer additional programs as part of its continual expansion (University of Education, 2015).

The sample university produces dynamic leaders and practitioners in the field of teaching, research, and management. There are total 17,700 Students enrolled in academic programmes offered by the University.

The sample university has no main library. However, its campuses and divisions have their own libraries. The University has started numerous new programmes during the last 5 years, the number of students has increased, but the setup of libraries of the university remained the same.

Students are not satisfied with the facilities provided and allocation of the library staff. So the importance of knowing the perceptions and expectations of students regarding the SQ of libraries.

Under the changing environment it is not enough to evaluate quality of traditional indicators such as size of collection of library material, number of library staff, and library budget only. New techniques of evaluation have been developed to better determine SQ of libraries. The past researches has indicated that there are number of techniques for evaluating the SQ of libraries such as user surveys, interviews, observational techniques, check lists and suggestion box. Some tools for evaluation have been developed mainly in business and trade area such as SERVQUAL and SERVPERF.

SERVQUAL has been used both in profiteering and non-profiteering organizations. This study has been organized to judge the student's perceived SQ of university libraries using SERVQUAL. Although SERVQUAL can be modified to evaluate SQ of specific library services; however, SERVQUAL has been adapted for the evaluation of overall SQ of libraries.

To judge students' expectations regarding ideal library services and perceptions of actual library performance, a seven-point, semantic differential scale has been used to get the response for 22 statements regarding different aspects of quality library services.

\section{Statement of the Problem}

The discussion mentioned above revealed that it is need of the hour to evaluate the library SQ due to emerging information communication technology and rising expectations of library users. The evaluation of SQ in libraries does not have much research work in its credit. Therefore, there is need to evaluate the SQ of libraries.

\section{Objective of the Study}

To study the SQ by calculating the gap between the students' perceptions and expectations and hence giving recommendations for the improvement of the services of the university libraries.

\section{Rationale and Significance of the Study}

This research work will explore the perceptions and expectations of students regarding library facilities and services. This will also expose the SWOT analysis of library services and offered valuable data for librarians for further improvement of SQ. It will be important for librarians to change and set the focus and direction of library services to meet student's demand. 
It is expected that university libraries may benefit from the findings of this research work in discovering user's expectations, analysing service polices, and reconsidering resource allocations.

\section{Delimitations}

The present study included all 10 campuses and 3 divisions of the the sample university offering different programmes. The study delimited to bachelor and master level students because of time and financial constraints.

\section{Methodology}

\section{Population and Sampling}

Morning students of bachelor's and master's programs of session 2013-14 were used as population $(N=5163)$ of the study. Stratified proportionate random sampling technique was applied to determine the sample size $(n=372)$. Four different programmes offered by the university were taken as strata.

Table 1

Sample distribution by program category

\begin{tabular}{llll}
\hline Program Categories & No. of Total Students & $\begin{array}{l}\text { Selection of } \\
\text { sample }\end{array}$ & students as \\
\hline BBA & 700 & 50 & \\
Education\& Special Education & 2539 & 182 & \\
\hline
\end{tabular}

\begin{tabular}{lll}
\hline Fine arts and social sciences & 821 & 60 \\
Natural Sciences & 1103 & 80 \\
Total & 5163 & 373 \\
\hline
\end{tabular}

Note. Yamane (1967) Sample Size $=\mathrm{n}={ }^{N}$

$1+(e) 2$

Where $\mathrm{N}=$ size of Population $\mathrm{e}=$ margin of error $=1-$ confidence interval $=.05$ Confidence Interval $=95 \%$

\section{Data Collection}

A self-completion questionnaire based on the SERVQUAL pattern was used to collect data for evaluating students' preferences and perceptions. As per the suggestion of Babbie (2002) for proper survey research design, both structured and unstructured questions should be included. Closed-ended questions rated using seven points scale with $(1=$ extremely good $)$ to $(7=$ extremely poor). Questionnaires were distributed directly to the target students. The response rate was almost $80 \%$ (296 out of 372 ).

\section{Analysis of Data}

The questionnaire was consisting of three sections: demographic questions, closed-ended questions consist of 22 items, and open-ended questions. The researcher used SPSS version 20 for analysis of data. Whereas for open-ended questions, content analysis was performed using $\mathrm{N}$ Vivo 10 for windows.

\section{Demographic Analysis}

According to results of demographic data, the females dominated (72.3\%), age group 18- 27 years $(99.7 \%)$, students of bachelor's level (53.4\%), in education/special education program (46.3\%), and who do visit library once in a week (35.8\%).

\section{Expectations and Perceptions of students regarding SQ of Libraries}

Expectations are the demands of users regarding library services while perceptions are the beliefs of users regarding library services (Parasuraman et. al., 1988). The data reflect students' 
expectations of library services lingered on higher side within a range of 5.02 to 5.46 (mean value $=5.28$ ) with standard deviations from 1.52 to 1.92 .

Students' perceptions were described by Hernon and Altman (1988) as impressions created from library interactions about the library services given to them. Students' perceptions about library services were on lower side within a range of 3.35 to 4.03 (mean value $=3.68$ ) with standard deviations from 1.61 to 1.93 . Item ranks with respect to mean values of expectations and perceptions are also given in descending order.

Last column in table 5 conveys gap between perceptions and expectations. Values of these gaps are between -1.33 and -1.88 (mean gap $=-1.60$ ).

\section{Analysis regarding SQ Attributes}

Table 2

\begin{tabular}{|c|c|c|c|c|c|c|c|}
\hline \multirow[t]{2}{*}{ SQ Attributes } & \multicolumn{3}{|c|}{ Expectations $(\mathrm{E})$} & \multicolumn{3}{|c|}{ Perceptions $(\mathrm{P})$} & \multirow{2}{*}{$\begin{array}{l}\text { P-E } \\
\text { Gap }\end{array}$} \\
\hline & Rank & Mean & SD & Rank & Mean & SD & \\
\hline Appearance and dressing of library staff & 1 & 5.46 & 1.76 & 1 & 4.03 & 1.84 & -1.43 \\
\hline Provision of library services & 2 & 5.46 & 1.62 & 2 & 3.95 & 1.75 & -1.51 \\
\hline Library staff is consistently polite & 3 & 5.46 & 1.64 & 3 & 3.93 & 1.90 & -1.53 \\
\hline Convenient Library Timings & 4 & 5.45 & 1.78 & 6 & 3.82 & 1.93 & -1.63 \\
\hline Performing of library services for students & 5 & 5.41 & 1.53 & 10 & 3.70 & 1.76 & -1.71 \\
\hline $\begin{array}{l}\text { Students are assured regarding } \\
\text { confidentiality of library services }\end{array}$ & 6 & 5.39 & 1.56 & 4 & 3.88 & 1.75 & -1.51 \\
\hline \multirow[t]{2}{*}{ First hand provision of library services } & 7 & 5.33 & 1.67 & 12 & 3.62 & 1.72 & - \\
\hline & & & & & & & 1.71 \\
\hline Reliability in solving students service problems & 8 & 5.32 & 1.67 & 5 & 3.84 & 1.73 & -1.48 \\
\hline Providing service at the promised time & 9 & 5.30 & 1.74 & 19 & 3.50 & 1.77 & -1.80 \\
\hline Willingness of library staff to help students & 10 & 5.29 & 1.74 & 15 & 3.55 & 1.77 & -1.74 \\
\hline Library Staff who have the student's best interest at heart. & 11 & 5.29 & 1.72 & 18 & 3.53 & 1.77 & -1.76 \\
\hline $\begin{array}{l}\text { Students' queries are answered by the skilled and knowledg } \\
\text { able library staff }\end{array}$ & 12 & 5.26 & 1.7 & 20 & 3.48 & 1.81 & -1.78 \\
\hline Giving students individual attention & 13 & 5.25 & 1.65 & 17 & 3.53 & 1.78 & -1.72 \\
\hline Up to date equipment in the library & 14 & 5.23 & 1.74 & 22 & 3.35 & 1.73 & -1.88 \\
\hline Dealing Students in caring fashion & 15 & 5.23 & 1.63 & 13 & 3.6 & 1.61 & -1.63 \\
\hline $\begin{array}{l}\text { Library maintains error free students and library materi } \\
\text { catalogue records }\end{array}$ & 116 & 5.22 & 1.71 & 9 & 3.76 & 1.71 & -1.46 \\
\hline Respond to student's queries by the library staff & 17 & 5.21 & 1.61 & 11 & 3.69 & 1.71 & -1.52 \\
\hline Library staff understands the needs of their students & 18 & 5.15 & 1.81 & 21 & 3.43 & 1.78 & -1.72 \\
\hline Timely provision of library services for students & 19 & 5.15 & 1.52 & 14 & 3.56 & 1.68 & -1.59 \\
\hline $\begin{array}{l}\text { Students' problems regarding library services are solv } \\
\text { symphethetically. }\end{array}$ & & 5.12 & 1.92 & 7 & 3.81 & 1.89 & -1.31 \\
\hline
\end{tabular}


Physical facilities are aligned with the services provided by 21 the libraries

Visually appealing physical facilities

$22 \quad 5.02$

$\begin{array}{lllll}1.68 & 8 & 3.76 & 1.62 & -1.33 \\ 1.75 & 16 & 3.54 & 1.71 & -1.48\end{array}$

\section{Service Quality (SQ)}

In terms of differences, all 22 elements may be classified as category B(-1 to-2), which denotes "a marginally positive or neutral overall consistency of the relationship and satisfaction with the service. A lot of work needs to be done on this relationship right now.

\section{Academic Level (Cross-tabulation)}

Cross-tabulation of two major categories show that bachelor's students have higher expectations but similar perceptions about library services as compared to master's degree students. Quality gap for bachelor's students and master's students remained -1.7 and -1.4 respectively.

Table 3

\section{Response of students' expectations and perceptions based on academic status}

\begin{tabular}{llll}
\hline $\mathbf{A S}$ & $\mathbf{M}(\mathbf{E})$ & $\mathbf{M}(\mathbf{P})$ & $\mathbf{G}(\mathbf{P}-\mathbf{E})$ \\
\hline Undergraduate & 4.4 & 2.7 & -1.7 \\
Masters & 4.1 & 2.7 & -1.4 \\
\hline
\end{tabular}

Note. $\mathrm{M}(\mathrm{E})=$ Mean Expectation $\mathrm{M}(\mathrm{P})=$ Mean Perception $\mathrm{G}(\mathrm{P}-\mathrm{E})=$ Gap (Perception-Expectation)

Overall SQ

Overall service quality of library was measured through seven-point scale $(1=$ extremely poor to 7 = extremely good). It was found that $37 \%$ students were dissatisfied, $42 \%$ are undecided, whereas only of $21 \%$ students are satisfied with the services provided by the university library.

Table 4

Overall Service Quality

\begin{tabular}{llll|}
\hline 7 Point Scale & Frequency & Percentage & Comments \\
\hline Extremely Poor & 38 & 12.8 & Zone of dissatisfaction \\
Very Poor & 32 & 10.8 & \\
Poor & 39 & 13.2 & Neutral \\
Undecided & 125 & 42.2 & Zone of satisfaction \\
Good & 27 & 9.1 & \\
Very Good & 26 & 8.8 & \\
Extremely Good & 9 & 3.0 & \\
Total & 296 & 100.0 & \\
\hline
\end{tabular}

\section{Examining the Expectations of Students}

Students were asked to mention any other aspirations they had in an open-ended query. Only 123 people (out of a total of 296) replied to the issue. Open ended questions have a lower answer rate (42\%) than closed ended questions. NVivo software was used for qualitative data analysis. The data collected through interviews were transcribed and entered into software. Data were further classified into parent and child themes. Following were the parent themes of the data.

Physical facilities provided by the libraries

Collection development 
Infrastructure maintained by library

Appearance and dressing of library staff

Timings and other miscellaneous expectations.

\section{Conclusion}

Based on the qualitative findings, it was concluded that the most important library SQ expectations for students were; Staff who are well-dressed and attractive, who provide facilities as expected, and who treat students with respect. Students have a positive impression of library hours that are convenient. The SQ attributes which were perceived somewhat well were that library staff was well dressed and appeared neat. The staff had been providing good services to the library users.

\section{References}

Ameen, K. (2005). Developments in the philosophy of collection management: a historical review. Collection Building, 24,112-116.doi: 10.1108/01604950510629264

Andaleeb, S.S., \& Simmonds, P.L., (1998). Explaining user satisfaction with academic libraries: Strategic Implications. College \& Research Libraries, 59(2), 156-167.

Awan, M.U., Azam, S., \& Asif, M. (2006). Library service quality assessment. Journal of Total Quality Management, 4(1), 51-64.

Babbie, E. (2002). The Practice of Social Research (8th ed). Belmont, CA: Cengage.

Calvert, P.J., \& Hernon, P. (1997). Surveying service quality within university libraries. 408415.

.Coleman, V., Xio, Yi (Daniel). \& Bair, L., Chollett, B. (1997). Toward a TQM paradigm: Using SERVQUAL to measure library service quality. College \& Research Libraries, 58(3), 237-249.

Cook, C. \& Heath, F. (2001). User's perceptions of Library Service Quality: A LibQUAl+TM Qualitative Interview Study. Library Trends, 49(4), 548-584.

Cook, C., \& Thompson, B. (2000). High Order Factor Analytic perspective on user's perceptions of library service quality. Library Information Science Research, 22, 393- 404.

Cook, C., Thompson, B. (2000). Reliability and validity of SERVQUAL scores used to evaluate perceptions of library service quality. Journal of Academic Librarianship, 26, 248-258.

Crawford, J. (2000). Evaluation of Library Information Services (2nd ed). London Aslib

.Crawford, J. (2006). The culture of evaluation in library and information services, Oxford: Chandos.

Cronin, J.J., \& Taylor, S.A. (1992). Measuring Service Quality: A reexamination and extension. Journal of Marketing, 56(3), 55-68.

De Saez, E.E. (2000). Marketing concepts for libraries and information services (2nd ed.).London Facet Publishing.

Edwrads, S. and Browne, M (1995).Quality in Information Services: Do Users and Librarians differ in their expectations? Library and information Science Research 17,163-182.

Elliott K.M. (1995). A comparison of alternative measures of service quality: journal of customer service in Marketing and Management, 1(1), 35.

Evans, G.E., Ward, P. L., \& Rudaas, B. (2000).Management basics for Information Professionals. New York Neal-Schuman Publishers, Inc.

Evans J. R., \& Lindsay, W.M. (2004). The management and control of quality (5thed). Mason Ohio Thomson south western.

Green, S.S. (1876). Personal Relations between Librarians and Readers: Library Journal, 1, 7481.

Haider, S J. (2004). Perspectives on Coping with Change: Issues facing University Libraries in Pakistan. The journal of academic librarianship .2(3), 229-236.

Harwood, N., \& Budder, J. (1998) Student Expectations of and Satisfaction with the University library. The journal of academic librarianship 161-171. 
Heath, F., \& Cook, C. (2003). SERVQUAL: Service Quality Assessment in libraries .In

Encyclopedia of library and information science (2nd ed. Vols. 1-3, pp. 2613-2625).New York: Marcel Dekker.

Hernon, P. (2002).Quality: New Directions in the Research. The Journal of Academic Librarianship, 28(4), 224-231.

Hermon, P., \& Altman, E. (1998). Assessing service quality satisfying the expectation of library customers. Chicago: American library Association.

Hernon, P. (2002).Quality: New Directions in the Research. The Journal of Academic Librarianship, 224-231.

Hernon, P., \& Nitecki, D.A. (2001). Service quality: A concept not fully explored. Library trends, 49(4) 687-708.

Hernon, P., Nitecki, D.A,. \& Altman, E. (1999). Service quality and customer Satisfaction: An Assessment for future directions. The journal of academic librarianship, 25(1), 9- 17.

Jabeen, M. (2004). Lahore kay amity kata khan ki madi wa Tibee sahoolat. (Unpublished master's thesis) University of the Punjab, Lahore.

Kent, A., lancour, H., and Daily, J.E (1978). Evaluation of library services. In encyclopedia of library and information science (Vols. 1-33, pp.317-320). New York: Marcel Dekker, Inc. 